\title{
The Analysis Of Foreign Tourists' Perception Towards Physical Evidence
}

\author{
Ariance Ana Lasibey ${ }^{1}$, Christin Plaituka ${ }^{1}$, Martarida Bagaihing ${ }^{1}$ \\ \{rinlasibey@gmail.com, chiristinplaituka@gmail.com, ridabagaihing@yahoo.co.id \\ Politeknik Negeri Kupang, Indonesia ${ }^{1}$
}

\begin{abstract}
This research is located on Fatumnasi as one of the tourism destination in East Nusa Tenggara, South Central Timor. The aim of this case study knows the international tourists' perception towards the amenities. The method of this research is qualitative with quantitative approach. Total sample of this research is 40 respondents' international tourism. The technique of gathering sample used accidental sampling. The analyzing of the data used validity and reliability test, importance performance analysis with Likert scale. The result of this research showed that international tourists' perception towards the amenities on Homestay 'Lopo Mutis' in Fatumnasi Tourism village was good.
\end{abstract}

Key words: perception, tourists, physical evidence

\section{Introduction}

The development of tourism in the village, homestay is one of the supporting factor that must be owned by the village residents because the homestay has an important role in giving great experience to foreigner. It means that the foreigner is encouraged to develop with local society.

Homestay also as an accommodation business in the field of tourism is generally built in rural areas (rural destinations), it is expected to provide welfare for rural communities, as a place to stay for tourist, and as a moment to feel and learn firsthand the natural environment and local culture (unique and interesting), of course with " pay "various things such as clean room facilities, clean drinking utensils. But specifically to find out the level of tourist satisfaction about homestay is still lacking in publicity Mertha and Pitanatri [1].

One of the tourist villages in East Nusa Tenggara, especially in South Central Timor Regency is Fatumnasi. This tourism village provides tourists with some natural beauty including, the Teletabis hill pine forest or "Bola Palelo", and marble mining. While to meet the needs of tourist stays, a "Lopo Mutis" Homestay business was established and owned local resident and also as local leader by Mateos Anin. This homestay is set on a hill so tourists, especially foreign tourists, can enjoy the atmosphere of sunrise and sunset. The "Lopo Mutis" homestay was established in 2010 with 4 zinc-roofed lodgings, but to further highlight the characteristics of the local culture, the zinc roof was replaced with a roof of reeds. While the kitchen and dining area is shared with the owner and other guess of the homestay.

Based on the results of surveys and interviews with homestay owners, it is known that many homestay visitors are foreign tourists who use the "Lopo Mutis" homestay. This can be seen in "Table 1 " 
Table 1. Number of Foreign Tourist Visits Homestay "Lopo Mutis" January-August 2019

\begin{tabular}{ll}
\hline Months & Year \\
\cline { 2 - 2 } & $\mathbf{2 0 1 9}$ \\
\hline Januari & 10 \\
February & 12 \\
March & 11 \\
April & 15 \\
Mai & 3 \\
June & 3 \\
July & 7 \\
August & 16 \\
Jumlah & 77 \\
\hline
\end{tabular}

From the data on the table above it is also known that the average monthly stay is $9-10$ foreign tourists that can be seen the increasing of the number of visitors. These are happened because there are some natural tourism objects and cultures that are becoming the goal of the tourists come and visit. Natural tourism, such as: Natural Heritage of Mutis, Natural Bonsai Forest, Boni Benfani waterfall, Lelo Fui hill, Dua Putri Oenino Cave, Marble Mountain, Nua Bua Bat Cave. In addition, cultural tourism includes: traditional dance, traditional fabrics or woven and traditional houses. Based on the results of interview, the problems encountered in homestays feel unsatisfied with small-size rooms without air circulation with a small size bed and a less clean mattress, and also without rubbish bin.

Amenities for the "Lopo Mutis" Homestay is more indicated for the appearance of the homestay physical facilities of the exterior and interior facilities and other facilities in the "Lopo Mutis" Homestay. Based on the background above, the research problem is "What are the perceptions of foreign tourists towards the amenities of Lopo Mutis Homestay in the tourist area of Fatumnasi Village?" Knowing tourists' perceptions of amenities at "Lopo Mutis" Homestay can be an input to improve the management of homestay facilities without eliminating the characteristics of local culture. The urgency of research from applied research is seen from several aspects, such as: (1) Economic Aspects Value Bringing economic improvement to the local residents of Fatumnasi Village with open jobs such as tour-guide, souvenirs and woven, (2) Social Aspects Value :Increased the understanding of good homestay facility management.

\section{Literature Review}

\subsection{Perception}

Kotler [2], explains the notion of perception is where we choose, organize, and translate information input to create a meaningful picture of the world.

According to Gibson, et al in Rahmatullah [3], there are 2 factors affect perception, these factors are as follows:

1. Internal factors that influence perception, namely the factors contained in individuals that include several things, such as:

a. Physiological Information entered through the senses, then the information obtained will affect and complete efforts to perceive 
different people so that interpretation of the environment can also be influenced.

b. Individual attention requires the amount of energy expended to pay attention or focus on the physical form and mental facilities that exist on an object. The energy of each person is different so that one's attention to objects is also different and this will affect the perception of an object.

c. Interest in Perception of an object varies depending on how much energy or perceptional vigilance is driven to perceive. Perceptual vigilance is a person's tendency to pay attention to a particular type of stimulus or can be said to be of interest.

d. Directional Needs, this factor can be seen from how strong an individual is looking for objects or messages that can provide answers according to themselves.

e. Experience and Memory can be said to depend on memory in the sense of the extent to which a person can remember past events to know a stimulus in the broadest sense.

f. Mood Emotional states affect one's behavior, this mood shows how someone's feelings at times can affect how a person receives, reacts and remembers.

2. External factors that affect perception are characteristics of the environment and the objects visible there in. These elements can change a person's perspective of the world around him and influence how a person feels it or accepts it. Meanwhile external factors that influence perception are:

a. Size and Placement of the Object or Stimulus. This factor states that the greater the relationship of an object, the easier it is to understand. This form will affect individual perceptions and by seeing the shape of the size of an individual object it will be easy for attention to in turn shape the perception.

b. The colors of the objects that affect the light more will be easier to understand (to be perceived) compared to the least.

c. The Uniqueness and Contrast of the Stimulus 15 An external stimulus whose appearance against the background and its surroundings is completely beyond the expectation of other individuals will attract much attention.

d. Intensity and Strength of a Stimulus from the outside will give meaning to the attention more often than what is only seen once. The strength of the stimulus is the power of an object that can affect perception.

e. Motion or Movement Individual will pay more attention to objects that provide movement in the range of vision compared to a stationary object.

\subsection{Tourists}

Tourists are people who are doing tourism activities [4]. Dama Adhyatma,[5]. Classify tourists as follows:

1. Foreign tourists (foreign tourists) are foreigners who travel, who come into another country that is not a country where he usually lives. (usually can be seen from the status of citizenship, travel documents, and the type of money spent)

2. Domestic foreign tourist is a foreigner who lives in a country, who travels in the area of the country where he lives (such as someone who works at an embassy). 
3. Domestic tourist is a person who is a national of a country who travels within the boundaries of his own country without crossing his country's borders.

4. Indigenous Foreign Tourist is: Citizens of a certain country, who because of their duties or position abroad, return to their home country and travel in their own country.

5. Transit tourist is: tourists who are traveling to a particular country, boarding an airplane or ship or train, who are forced to stop by or stop at a port / airport / station not of their own volition.

6. Business tourist is a person who travels (whether a foreigner or a citizen of his own) who travels for other destinations, not tourism, but will travel after the main destination is completed.

7. Backpacker is a type of tourist who does tourism activities with limited funds. Therefore, these tourists usually use local standard facilities.

8. Visiting friends and relatives is a type of tourist who has a specific purpose, namely visiting friends and relatives. This type of tourist is usually managed by friends and relatives themselves, ranging from residence, food, to transportation.

9. Excursionists are tourists who visit a place in less than 24 hours. This includes tourists of this type for example cruise ship passengers who stop by to an area.

10. Educational tourist is a tourist who travels for educational purposes, for example for study or comparative studies at a school or university.

11. Religious tourists are tourists who take holy trips to places related to religion, such as pilgrimage, tirta yatra, and so on.

12. Snowbird is a type of tourist from a cold-season country who travels to tropical regions.

\subsection{Homestay}

Homestays are divided into 2 types namely Homestay Pondok Wisata and Homestay a. Rumah Wisata.

Homestay Pondok Wisata is an effort to provide services to the public with a daily payment made by a person by using a residential building that is inhabited by the owner and is used in part to be rented by giving a chance on a tour of the person to interact in the life of his day-life "[6]

Vacation Rentals include short-term accommodation, other types: bungalows, cottages, etc. Provision of accommodation in the form of a housing unit with a complete line of electricity in accordance with local culture and resources owned by the emperor, community, Cooperatives, village fund, and / or Government in tourism or tourism managed by the local community groups in tourism based on tourism (KEMENPAR)

\subsection{Amenities}

Physical Evidence is a physical environment where the services are created and direct interaction with consumers. In the tourism industry, managing physical evidence by using a viable element to strengthen the meaning or value of intangible points is an important strategy in marketing services. Zeithaml at al [7] mentions that physical evidence can be seen from exterior facilities (exterior design, signage, parking landscape, surrounding environment, facility interior, air quality / temperature, Sound / music / lighting). Other gibles (business cards, stationery, billing statements, reports, employee dresses, uniforms, brochures, web pages, virtual service scape).

Zeithaml, et al [8] mentions the main elements of amenities/Physical Evidence: 
a. Facility exterior: building / exterior building, signage, parking area, landscape, surrounding environment

b. Interior facilities: interior design, equipment, layout

c. Other Tangible / appearance and capability of physical and environmental marketing sensations: brochures

\subsection{Current Research}

Kurniansah [9] in the journal tourist perceptions and expectations of Lakey-Hu'u tourism destination components, Dompu District with the aim of research to find out the determining components of Lakey-Hu'u tourism destinations, examine tourist perceptions and expectations of the quality of Lakey tourism destination components. Hu'u, as well as the improvisation program components of Lakey-Hu'u tourism destinations. Using qualitative descriptive, Likert scale and importance performance analysis.

\section{Research Method}

This research is a qualitative study with a case study approach. This research focuses on intensive study on a particular project those studies as a case Nawawi (2005: 1). The source of the data used is qualitative and quantitative data sourced from Survey, Interview and Questionnaire. The number of samples used was 40 international tourism respondents who stayed at the Lopo Mutis Homestay. The determination of the data was using accidental sampling technique and sugiyono [10] Accidental sampling is taking respondents as samples based on accidental findings.

\section{Discussion}

The distance from SoE City to Fatumnasi village is around 40 kilometers. Along the road will be decorated with traditional Timorese houses, namely the Bulat house "Ume Bubu" Ume Bubu is a typical Timor round house that is built from boards and roofed with gewang leaves. There is only 1 Lopo Mutis homestay located on the edge of the village main road. This homestay consists of several buildings in the form of round houses totaling 15 pieces. This homestay is the property of Mr. Mateos Anin, who has traveled the archipelago, often being a representative of NTT for various tourism events; in addition he is an elderly and also the Chief of Mount Mutis. Based on the distribution of questionnaires to 40 respondents, the perception of foreign tourists about physical evidence at Lopo Mutis Homestay can be seen from the table below: 
Table 2. Average Calculation of Perceptions Scores of Tourists Abroad Against Proof of Physical Homestay Lopo Mutis

\begin{tabular}{|l|r|r|r|}
\hline \multicolumn{1}{|c|}{$\mathrm{Nu}$} & \multicolumn{1}{c|}{ Level } & \multicolumn{1}{c|}{ Level } & \multicolumn{1}{c|}{ Level } \\
\hline Atribute & Kinerja & Kepentingan & Kesesuaian \\
\hline & (Xi ) & \multicolumn{1}{c|}{ ( Yi) } & ( Tki) $(\%)$ \\
\hline A1 & 146 & 182 & 80.22 \\
\hline A2 & 153 & 191 & 80.10 \\
\hline A3 & 136 & 175 & 77.71 \\
\hline A4 & 113 & 148 & 76.35 \\
\hline A5 & 130 & 170 & 76.47 \\
\hline A6 & 125 & 191 & 65.45 \\
\hline A7 & 130 & 179 & 72.63 \\
\hline A8 & 150 & 175 & 85.71 \\
\hline A9 & 152 & 164 & 92.68 \\
\hline Average & $\mathbf{1 2 3 5}$ & $\mathbf{1 5 7 5}$ & $\mathbf{7 8 . 4 1}$ \\
\hline
\end{tabular}

Table 1 above shows that for attribute A1 gets a score of 80.22, A2: 80.10 A3: 77.71, A4: 76.47, A5: 76.47, A6: 65.45, A7: 72.63, A8: 85, 71, A9: 92.68 with an average: 78.41, overall the perception of a tourist tour of the world against physical activity at the Lopo Mutis homestay is good.

Tabel 3. The result of Foreign Tourist's Perception Toward Phy sical Evidence Homestay " Lopo Mutis " at Tourism Village Fatumnasi - South Central Timor District

\begin{tabular}{|c|c|c|c|}
\hline $\begin{array}{c}\text { No } \\
\text { Atribute }\end{array}$ & Atribut & Score & Phy sical Evidence \\
\hline & \multicolumn{3}{|l|}{ Exterior Facility } \\
\hline $\mathrm{A} 1$ & The building of Homestay " Lopo Mutis" & 80,22 & Very Good \\
\hline $\mathrm{A} 2$ & The form of Homestay "Lopo Mutis" & 80,10 & Very Good \\
\hline A3 & Surrounding Enviroment & 77,71 & Good \\
\hline A4 & \begin{tabular}{|l|} 
Parking Area \\
\end{tabular} & 76,35 & Very Goog \\
\hline A5 & \begin{tabular}{|l|l} 
Signane &
\end{tabular} & 76,47 & Very Good \\
\hline & \multicolumn{3}{|l|}{ Interior Facility } \\
\hline A6 & The Room Facilities of Homestay & 65,45 & Good Enough \\
\hline A7 & The interior design of homestay & 72,63 & Good \\
\hline & \multicolumn{3}{|l|}{ The others Tangibles } \\
\hline A8 & The beautiful scienary $\backslash$ & 85,71 & Very Good \\
\hline A9 & Level of information & 92,68 & Very Good \\
\hline
\end{tabular}

Based on the results of the statement on Table 3, there is 1 physical attribute that has a score of 65.45 for Lopo Mutis homestay facilities.

\section{Conclusion and Suggestion}

Perception of the foreign tourist towards the amenities at Lopo Mutis Homestay based on the analysis of the results in general is very good. A facility for exterior especifically for the environment around is the cleanliness that must be put more attention such as availability of clean water and toilets. Interior facilities that get a good mark because the tourist is less 
comfortable with a small-size bed and also an unclean bed cover and pillow case, no air circulation and waste in the room in of Lopo Mutis Homestay. Throughout the physical activity consisting of exterior facilities, interior facilities and other facilities get a very good perception of tourists with 78,41 .

\section{Refrences}

[1] Amirullah, (2004). Pengantar Manajemen. Yogyakarta: Graha Ilmu.

[2] Arikunto, Suharsisni. (2002). Prosedur Peneltitian: Suatu pendekatan Praktek edisi revisi IV. Jakarta: PT Rineka Cipta.

[3] Bryson, John M. (2007). Penerapan Strategis bagi Organisasi Sosial. Yogyakarta: Pustaka Pelajar.

[4] Danim, Sudarwan. (2003). Menjadi peneliti Kualitatif. Bandung: Pustaka Setia.

[5] Hasibun, Melayu S.P. (2009). Manajemen Sumber Daya Manusia. Jakarta: P.T. Bumi Aksara.

[6] Kotler and Amstrong. 2012. Principles of Marketing 14th ed. Pearson Hall. New Jersey.

[7] Kotller, Philip dan Keller, Kevin Lane, 2012. Marketing Management 14eth edition. New Jersey: Prentice Hall

[8] Marpaung, Happy dan Bahar, Herman. (2002). Pengantar Pariwisata.Alfabeta, Bandung

[9] Mertha.I.Wayan., Pitanatri.PDiah Sastri. (2018) Homestay Mozaik Pariwisata Berbasis Kerakyatan: STP Nusa Dua Bali

[10] Meleong, Lexy. (2004). Metode Penelitian Kualitatif. Bandung: P.T. Remaja Rosdakarya. 